\title{
北海道における雪氷寒冷災害の原因，その対策及び 利雪(寒)の現状について
}

\author{
石川信 敬* 小 林 俊 一*,** \\ 堀口薰木下下誠一*
}

要 旨

\begin{abstract}
北海道は冬の期間が長く, 面積も広いために雪水寒冷災害の種類や原因は多岐にわたる，そこで 今後の有効な雪水寒冷災害の対策や利雪(寒)の方法を探る前段階として道内 212 市町村に対してア ンケートを出し，雪氷寒冷災害の現状を調查した，その結果，1) 災害対策費にはっきりとした地域 性が現われ，積雪の多い日本海側で多く，太平洋側では少ない，2)雪水寒冷災害の内，道路障害が 最も多く $(94.7 \%)$, 次いで家庭被害 $(80.0 \%)$, 学校被害 $(71.2 \%)$, 農作物被害 $(61.8 \%)$, 鉄道 障害 $(58.8 \%)$ ，道路破損 $(54.1 \%)$ であり，その原因の主なものは吹雪や吹き溜り，集中豪雪， 異常低温である。3)一方, 災害対策の主なものは除排雪であり, その他防風, 融雪促進, 路面滑り 防止等がある。 4) 利雪 (寒)の現状は, 雪(水)祭り, 及びスキー(スケート) 等の観光資源としての 活用が主なものである。 さらに規模は小さいが，農業用，工業用の水資源としての利用や，農作 物保存のための冷熱源としての利用もみられる.
\end{abstract}

\section{1. 緒 言}

積雪寒冷地域において雪害や寒害は避けることのでき ない宿命的なものと考えられていた，その災害の及ぶと ころは, 道路や鉄道の被害, 農作物被害, 一般家庭被害 など生活に直結したものが多い，これまで雪水寒冷災害 について数多くの報告があるが，その多くは，ある特異 な年にしぼって, 雪害や寒害のそれぞれの項目を調査 したものであった（国立防災科学技術センター 1982, 中峠 1981，札幌管区気象台 1981，仙台管区気象台 1974，北海道開発局 1969). 一方, 秋田谷ら (1981) は 社会現象としてとらえた雪害調査結果を報告している.

近年, 雪国に扔いて雪水寒冷災害対策の新しい試み, さらには雪や寒さを有効に利用する利雪・利寒の試みが なされるようになった（北日本新聞社 1984, 樋口敬二 監修 1983，木下誠一編 1982，青森県 1979). 北海 道に拀いては冬の期間が長く, さらには面積も広いため に, 雪水寒冷災害の種類やその原因も多岐にわたり，乙 かも地域性をもっていると思われる. そこで今回は今後 の有効な雪水寒冷災害対策や，利雪(寒)の方法を探る前 段階として, 毎年平均的に被害を受けている雪水寒冷災

\footnotetext{
* 北海道大学低温科学研究所

** 現 新潟大学積雪地域災害研究センター
}

害の種類とその原因，さらには，規模の大小，公私を問 わず，現在管内において実際に行なわれている対策とそ の施行場所, 及び利雪(寒)の方法について, 道内の自治 体に対しアンケート調査を行なった。な打沼野(1982) は 日本中の豪雪地帯の市町村について, 雪害と雪対策の実 態調査を行ない，豊富な資料を提出している。

\section{2. 調查方法}

調査は全道 212 市町村に対してアンケートを出し，あ らかじめ設定した項目の中から該当項目を複数回答して もらう方法をとった. 雪氷寒冷災害の種類は表 1 に示し たように $\mathrm{a} \sim \mathrm{u}$ の21項目, 原因は 1 20の20項目につい て設定したが, 回答を得た後, 災害の種類は道路障害 (a), 鉄道障害(b), 航空障害(c), 農作物被害(d), 船舶被害 (e), 家庭被害 $(\mathrm{f})$, 学校被害 $(\mathrm{g})$, 道路破損( $\mathrm{h}$, , その他( $\mathrm{i})$ の 9 項目, 原因は, 風と雪 $(1)$, 季節ハズレの気候(2), 低温 (3), 風と寒さ(4), 積雪(5), 流氷(6), 凍上 7 ), 雪崩(8), 融 雪(9), その他(10)の10項目にまとめて整理した. 災害対策 の種類としては $\mathrm{a} \sim \mathrm{j}$ の10項目, 手段は $1 \sim 17$ の 17 項目, 施行場所は $\mathrm{a} \sim \mathrm{h}$ の 8 項目を設定したが; 種類について は, 除排雪 $(a)$, 融雪 (促進) (b), 暖房 $(c)$, 防風(d), 雪崩 (e)，滑り防止(f)，その他の 7 項目にまとめた(表 2 )。利 雪・利寒の種類としては，観光資源 $(\mathrm{a})$ ，水資源(b), 冷熱 
表 1 アンケート調査項目一雪水寒冷災害の種類と原因

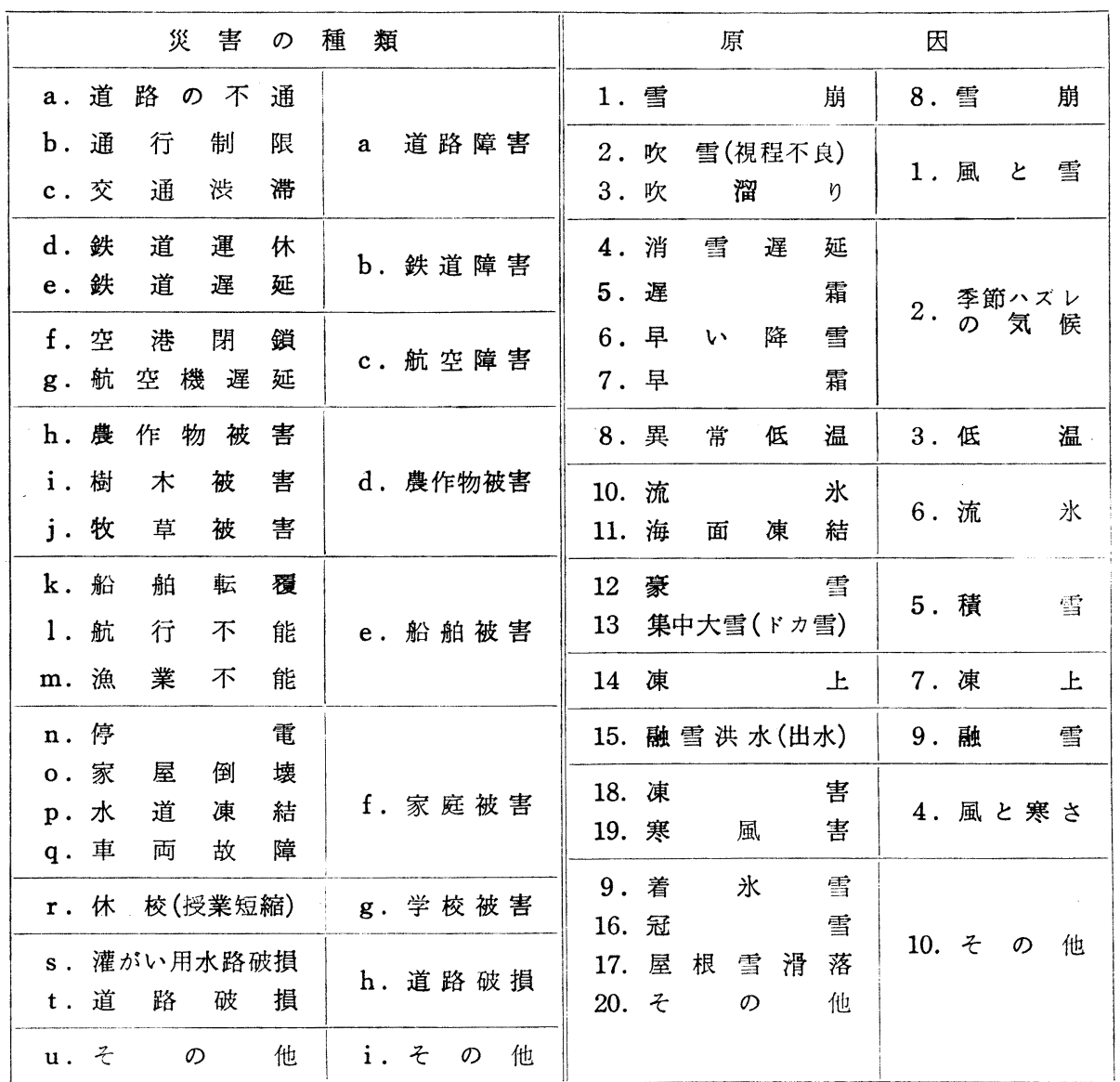

表 2 アンケート調查項目一災害対策の種類, 手段, 及び施行場所

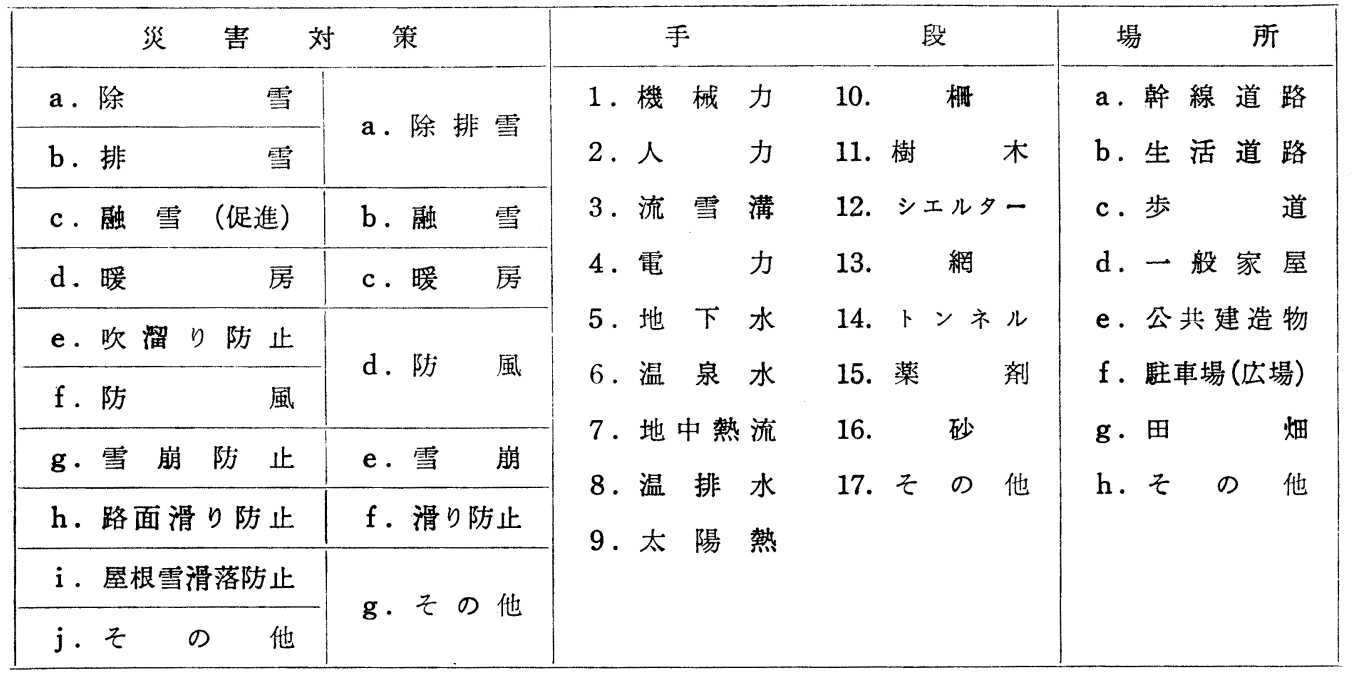


表 3 アンケート調査項目一利雪・利寒の種類と方法

\begin{tabular}{|c|c|c|c|c|c|}
\hline \multicolumn{3}{|c|}{ 利雪(寒)の種類 } & \multicolumn{2}{|l|}{ 方 } & 法 \\
\hline a. 鹳 & 光 資 & & a . 雪（水）ま & $\eta$ & f. I \\
\hline b. 水 & 資 & & b. スキー(スケート) & & $\mathrm{g}$. 生 活 一 般 \\
\hline c. & 熱 & 源 & c. 釣 & $\eta$ & h. 農作物等冷蔵保存 \\
\hline d. & の & 他 & d. 動 & 物 & i. 夏季の冷 房 \\
\hline & & & e. 農 & 用 & j. そ の 他 \\
\hline
\end{tabular}

源(c)，その他(d)の 4 項目，その方法は $\mathrm{a} \sim \mathrm{j}$ の10項目に 設定した（表 3 )。な打各市町村の人口と年平均雪水寒冷 災害対策費の回答も得た。

\section{3. 調查結果}

図 1 はアンケート回収率を支庁別に示したものであ る. 全道で調查対象となった 212 市町村の内 170 市町村 から回答を得た（回収率 $80.2 \%$ ). 回収率が最も高いの は後志 $(95.0 \%)$ ，低いのは桧山 $(50.0 \%)$ である。な 扣支庁毎の調査対象市町村数は空知, 上川, 網走, 十 勝，後志支庁で多く，根室，日高，留萌，石狩，桧山， 宗谷，釧路支庁は少ないが，今回は市町村の多少につい ては考慮せずにそのまま支庁毎の比較を行なった．

図 2 はアンケートの回答から集計した人口(a)と災害対 策費(b)を支庁別に示したものである．人口では石狩が最

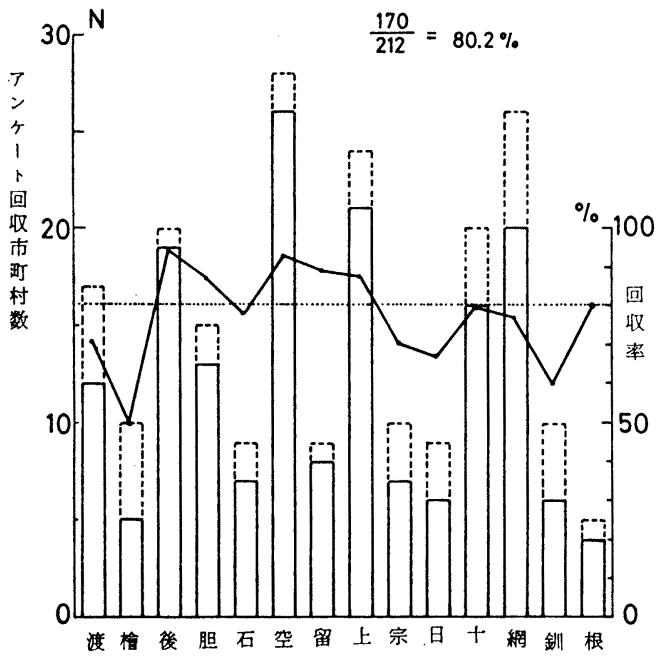

島山志振狩知萌川谷高勝走路室

图 1 支庁別アンケート回収市町村数と回収率 左軸 : 回答市町村数 (点数 : 支庁別市町 村数) 右軸：回収率（折線）
も多く（169 万人），上川，空知支庁の順になっている． しかし 道内の大都市では渡島支庁の函館市（32万人）， 胆振支庁の苫小牧市（15万人），網走支庁の北見市（10 万人）の 3 市から回答を得られなかったので，このグラ フは実際の支庁別人口の割合を表わしてはいない，なお 回答市町村の人口が全道の人口に占める割合は $85.3 \%$

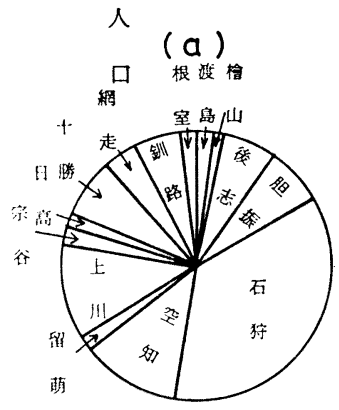

(4690916人)

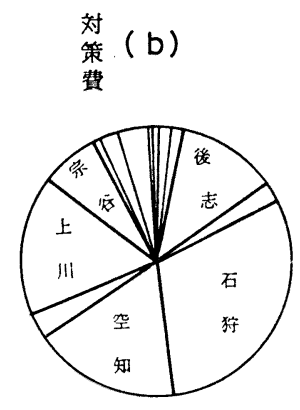

(1268861 JP)

(c)

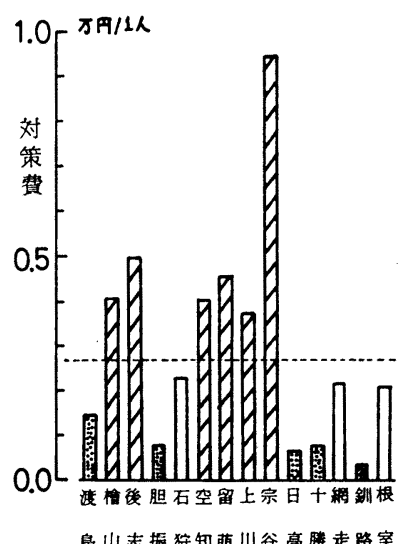

図 2 アンケートの回答から集計された支庁別の

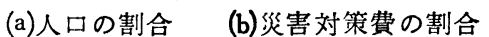

(c) 1 人当りの対策費（斜線部: 0.35 万円 $/ 1$ 人以上, ドット部：0.15万円 $/ 1$ 人以下, 白抜部 : $0.15 \sim 0.35$ 万円 $/ 1$ 人) 


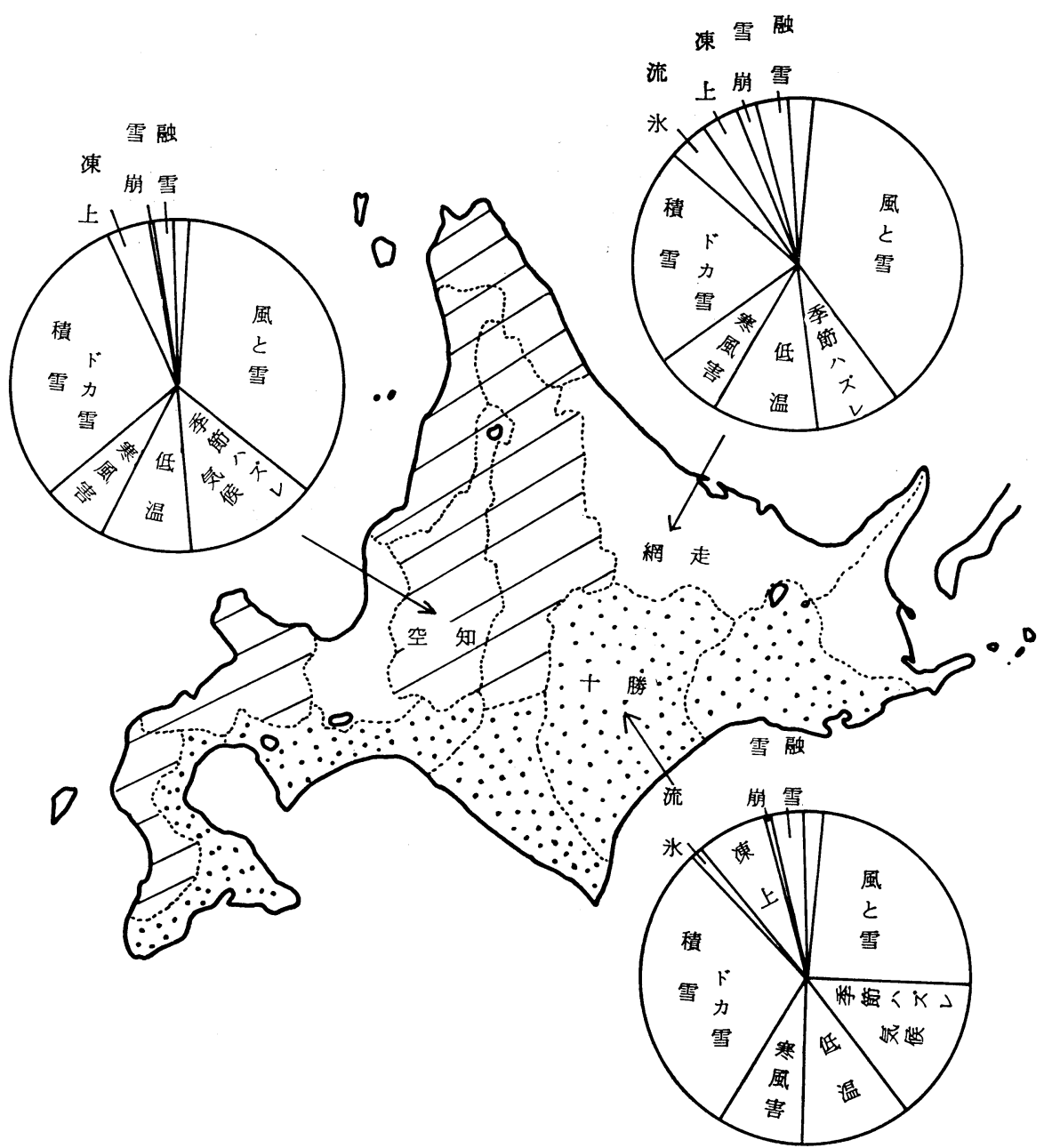

図 31 人当りの災害対策費と災害の原团

斜線部，ドット部及び白抜部は図 2 と同じ意味

（469万人/550万人）である. (b)四は支庁別災害対策費を 示したものであるが，全道で 126.9 億円の対策費が使わ れている.これは北海道開発局直轄の雪寒事業費の約 2 倍に匹敞する．なお招和57年度道開発予算によると，雪 寒事業費（除雪，防雪，凍雪害を含む）は直轄分が 64.4 億円であり，補助金を含めると 278 億円であった（北海 道開発局道路計画課監修, 1982)，支庁別の災害対策費は 人口の多い石狩，空知，上川支庁で大きな值となってい る．そこで各支庁毎の災害対策費を住民 1 人あたりで表 わしたものが(c)図である. 全道平均では 0.27 万円/ 1 人 となり, 負担の多い支庁は宗谷, 後志, 留萌, 桧山, 空 知，上川，少ない支庁は釧路，日高，胆振，十勝，渡島 である．対策費の多い（0.35万円/ 1 人以上）支庁を斜
線，少ない（0.15万円/ 1 人以下）支庁をドット，中程 度の支庁を白ぬきで示すと（図 3), 太平洋側で少なく, 日本海側で多くなっていることが分る. 図 4 は 19511980年の30年間平均最深皟雪深分布である（札幌管区気 象台, 1983). 積雪深が $100 \mathrm{~cm}$ 以上の地域を斜線で示し たが日本海側と道央側に多雪地帯がある. 圀 5 は1974年 11月 1 日 1975年 3 月 31日の一冬期間の積算寒度 $\Sigma T a$ ( $T_{a}$ は日平均気温 $\left.T_{a} \leqq 0^{\circ} \mathrm{C}\right)$ 分布を示したものである (福田他, 1975)。道東, 道北地方に寒度の極值がある. これらから図 2 に示した対策費は寒さよりはむしろ雪害 に対するものであることが分る. 宗谷支庁は積雪量が 多く寒さも厳しい気象条件に加えて, 人口が少ないため に，必要な雪害対策を行なうには割高になっている。一 


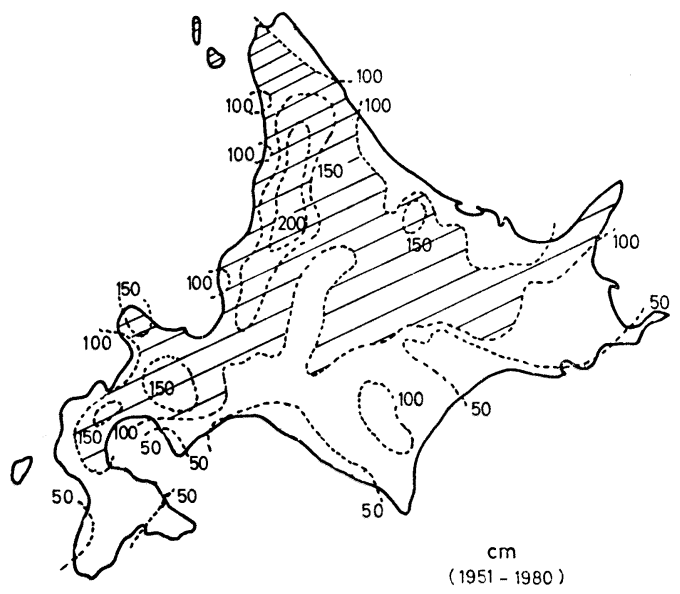

図 4 平均最深積雪深分布（1951年-1980年平均） 斜線部：積雪深 $100 \mathrm{~cm}$ 以上の地域

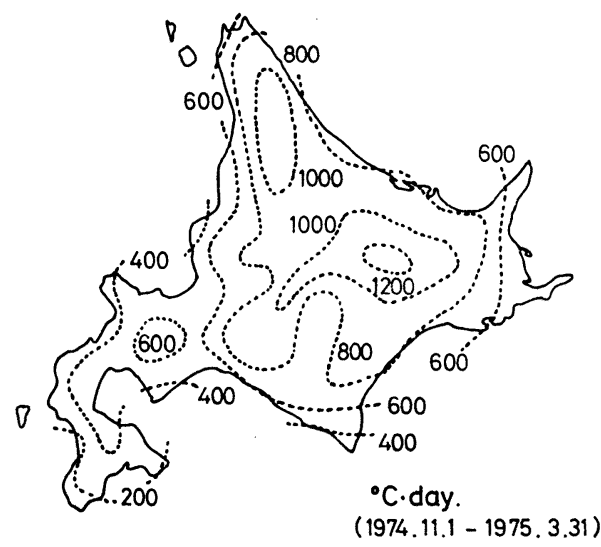

図 5 冬期間の積算寒度分布（1974年11月 1 日〜 1975年 3 月 31 日)

方，石狩支庁は日本海側位置しているが，札幌圈の多 人口のために，1人当りの対策費は少なめにでている. な打雪水寒冷災害対策費の地域特性を表わすには，この ような 1 人あたりの対策費とは別の方法も検討する必要 があろう．中峠ら（1978）は自然条件だけでなく，社会 的・経済的条件も考慮した積雪災害度を表わす指標を求 めており，その中で雪害対策事業費が，その地域の面積 にあまり依存しないことを報告している．

（1）雪水寒冷災害——その種類と原因一

图 6 は雪水寒冷災害の種類別発生頻度を各支庁毎に示 したものであり，縦軸は頻度 $N / N_{0}$ （ $N_{0}$ は各支庁毎の アンケート回答市町村総数, $N$ はそれぞれの雪水寒冷
災害項目を回答した市町村数）である. 全支庁に扔いて 災害発生頻度の第 1 位は道路障害（不通，交通制限，沿 漁）であり，次いで家庭被害（停電，家屋倒壊，水道凍 結，車両故障），学校被害（休校，授業短縮），鉄道障 害（遅延，運休）が多い，農作物被害（農作物，樹木， 牧草) は後志, 空知, 上川, 宗谷, 十勝, 網走の各支庁 で多くなっている (60\% 以上)，航空障害（空港閉鎖， 遅延）や船舶被害（転覆，航行不能，休漁）以管内に打 ける空港や港湾設備等の有無に左右されるが根室, 宗谷 に多く，道路破損（道路，灌溉用水路）は釧路，宗谷， 日高の各支庁で多くなっている.

次に雪水寒冷災害の種類每にその原因を検討した（全 道). 図 7 の縦軸は災害の種類毎にそれぞれの原因を挙 げた市町村数の割合 $N / N_{0}(\%)$ である $\left(N_{0}=170\right)$. 道 路障害や鉄道障害の主な原因は，吹雪(2)，吹溜り(3)（風 と雪による害)，豪雪(12)，ドカ雪(13)（積雪による害）で あり，雪崩害(1)は少ない，航空障害は飛行場施設をもた ない都市が多いために被害発生頻度は低いが，その原因 は上記の(2)，(3)，(12)，(13)が主なものである．船舶被害も 該当する市町村が少ないためにその発生頻度は低いが， 原因は上述の(2)，(3)，(12)，(13)の他に着水雪（6)，流氷(10)， 海面凍結(11)によるものがある. 農作物被害は季節ハズレ の気候（特に秋の早霜 7)や異常低温(8)）によるものが多 い，学校被害の主な原因は，吹雪(2)，ド力雪(13)である が，冬の異常低温８）による場合もある．家庭被害をもた らすものは冬の異常低温 8)がその代表的なものであり， 道路破損は凍上(14) と融雪洪水(15)によるものが多い。なお 近年，車両のスパイクタイヤによる道路破損が深刻な問 題となっている. しかし今回の調查では，この項目は除 外して気象条件によるものだけとした.

図 8 岋全雪水寒冷㷋害の原因を支庁別に示したもので ある. 円周に示した番号は, 表 1 右端の再整理後の原因 を示す番号（1～10）である.さらに同心円の半径は $N / N_{0}$ （ $N_{0}$ は各支庁每のアンケート回答市町村総数）で あり外側の円は $100 \%$ ，中の円は $50 \%$ を意味する.い ずれの支庁も風と雪(1)，及び積雪(5)が被害の主な原因に なっている. 特に後志, 石狩, 留萌, 上川, 宗谷, 網 走，釧路，根室支庁では風と雪(1)の害が高い，なお十勝 支庁は冬期間の積雪量が少ないにもかかわらず積雪 $(5)$ に よる被害が多くなっているが，これは冬の終わりの低気 压性のドカ雪によるものであろう，上川，宗谷，十勝， 網走，釧路支庁では低温害(3)の割合が高く，上川，宗 谷, 日高, 釧路支庁では棟上害(7)か影著であり, 網走, 釧路，根室では流氷害(6)が現われている.な打雪氷寒冷 災害の原因別割合を 3 支庁（日本海側の空知, 太平洋側 

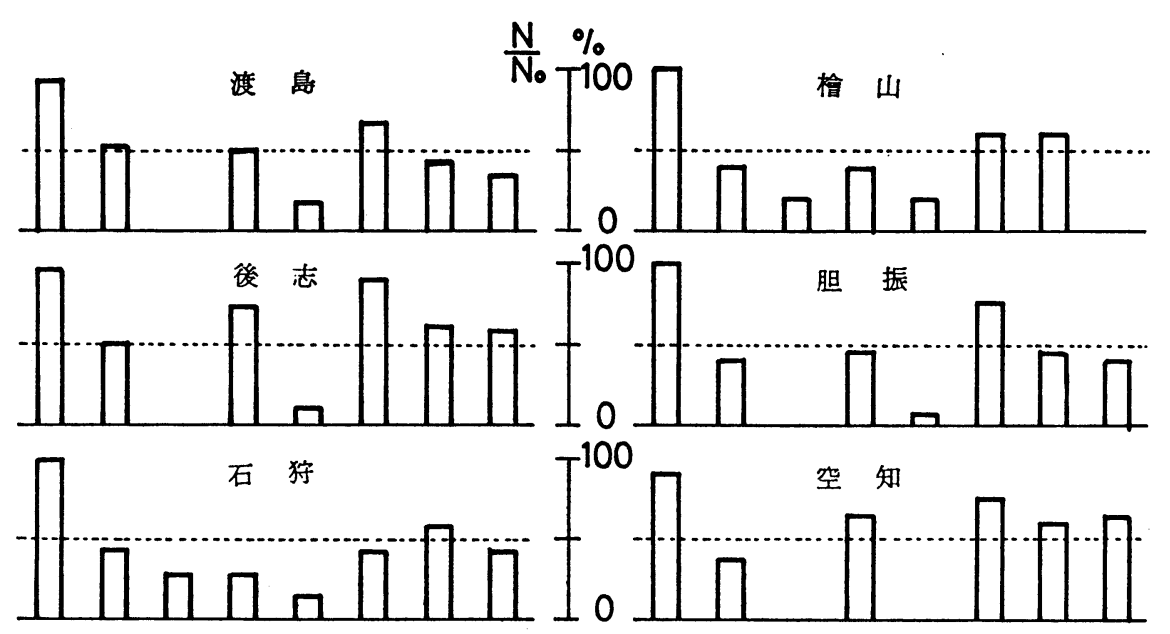

胆振
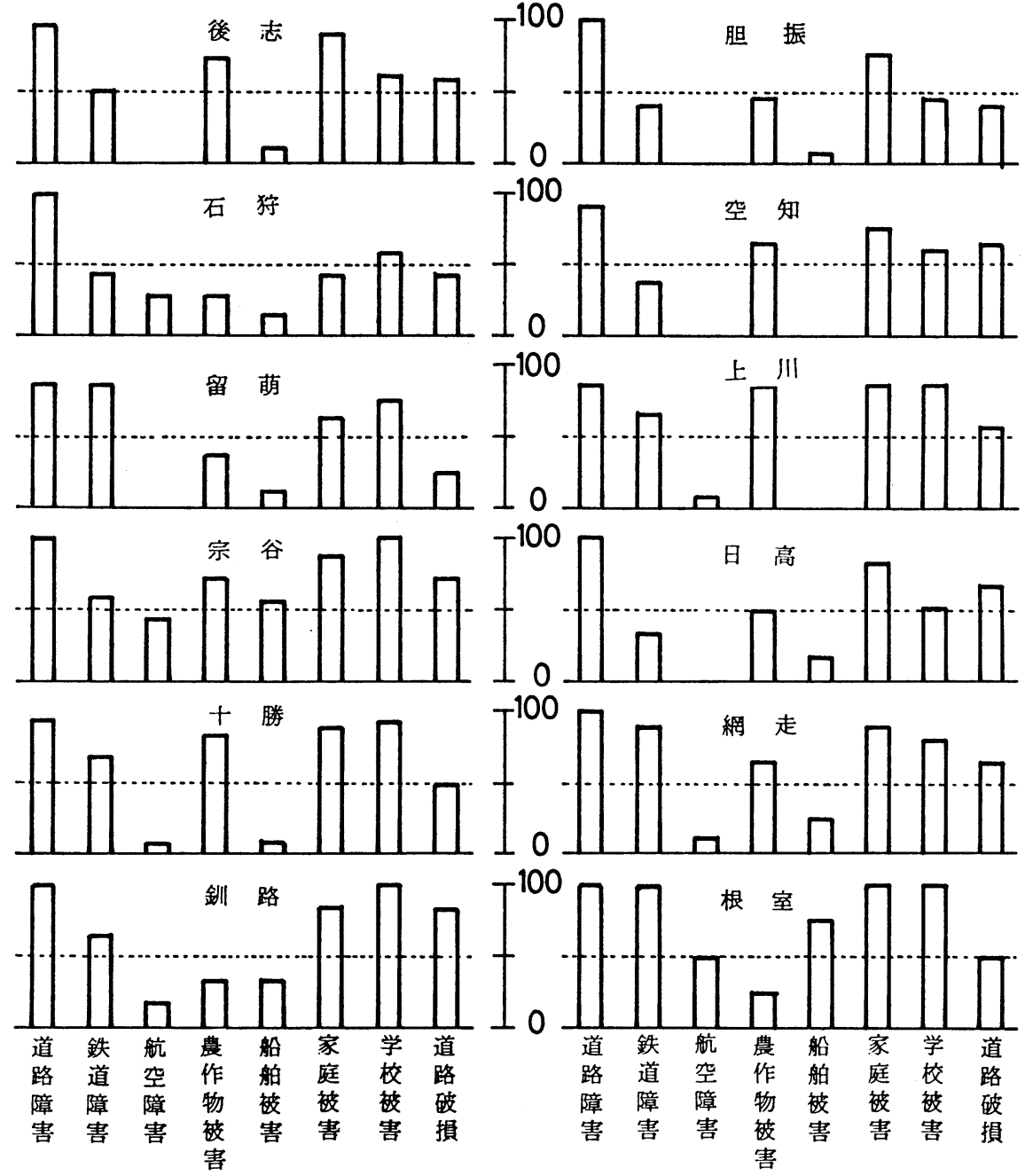

図 6 支庁毎にみた雪水寒冷災害の種類別発生頻度

の十勝，オホーツク海側の網走支庁）について図 3 に示 した.この 3 支庁はいずれもアンケート回答市町村数が 15以上と多く（図 1)，しかも1人あたりの災害対策費 が多，少，中間の地域をそれぞれ代表している(図2). いずれも風と雪, 積雪によるものが主であるが, 詳細に みると地域性がよく現われている，日本海側に比へて太 平洋側では雪と風の割合が減少し, 低温害（季節ハズレ の気候, 凍上害）がより顕著になっており，オホーック
側では雪と風による割合が增大し，流氷害の割合も增し ている.

北海道全域に打ける雪水寒冷災害の種類別発生頻度 （棒グラフ）とその原因の項目別割合（円グラフ）を図 9 に示した． 道路障害(a)の割合が最も高く $(94.7 \%)$, ついで家庭被害(f) (80.0\%), 学校被害(g) (71.2\%), 農作 物被害(d) (61.8\%)，鉄道障害(b) (58.8\%)，道路破損(h) (54.1\%) の順になっており，航空障害(c)や船舶被害(e) 


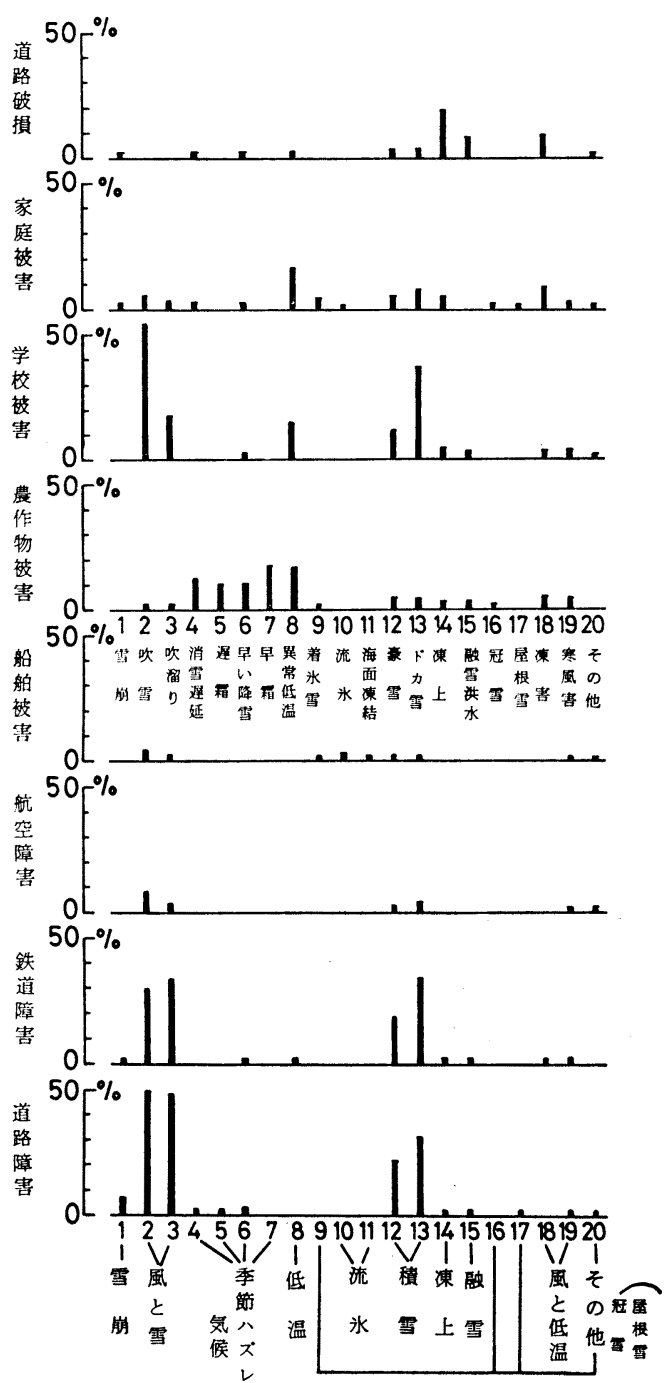

図 7 北海道全域における雪水寒冷災害の種類別原因

は災害の発生頻度としては低い值となっている，災害の 原因の項目別割合をみると吹雪と吹溜りによるものが $35.1 \%$ ，豪雪，ドカ雪によるものが $26.2 \%$ ，季節ハズ レの気候 $11.0 \%$, 異常低温 $8.6 \%$ となり，災害の中で も雪害を引きおこす項目が高い值をとっている.

(2) 雪水寒冷災害対策—その手段と施行場所—

次に上記の災害に対してどのような対策がとられてい るかを調査した。

困10は各支庁毎にとられている雪水寒冷災害対策の施 行率を，それぞれの対策を行なっている市町村数の割合 $\left(N / N_{0}\right)$ で示したものである. 除排雪はほぼ全市町村で 行なわれている。融雪（促進）は後志， $(66,0 \%)$, 宗谷 (55.0\%), 十勝 (50.0\%), 網走 $(50.0 \%)$ の各支庁で
多い，な打䁔房は石油や石炭を用いた一般家屋の䁔房以 外（新しいエネルギーの利用や温室等の暖房など）を調 查の対象とした. しかし回答方法に混乱が生じたよう で, はっきりした傾向を把握することは出来なかった が，網走 $(30.0 \%)$, 宗谷 $(28.0 \%)$, 上川 $(25.0 \%)$ で 比較的行なわれている. 防風対策は除排雪についで各支 庁で行なわれて打り宗谷 (82.0\%), 網走 (80.0\%), 桧 山 $(80.0 \%)$, 十勝 $(80.0 \%)$, 根室 $(70.0 \%)$ の各支庁 で高い値をとっている，雪崩対策は宗谷 $(55.0 \%)$ ，後 志 $(40.0 \%)$ 支庁で多くなっているが全道ではあまりな されていない，路面滑り防止は十勝 (70.0\%)，釧路 (70.0\%) 支庁など 雪の少ない地方で高い值になってい る. 次に，これらの対策に使用される手段の割合を図11 に示した (全道平均). 除排雪の方法は車両等を用いた 機械除雪と人力によるものが主であり, 融雪 (促進) は 薬剤散布が多い，暖房は電力によるもの以外に，温泉 水, 温排水, 太陽熱等の利用もみられる. 雪国の中でも 比較的暖かい北陸地方に打いては，以前から行なわれて いる水を用いた融雪・排雪法が, 近年北海道においても 行なわれ始めた (流雪溝の利用). 豊富な水量を確保出 来るか，排水に適した地形をもっているかなど設置条件 に解決すへき点も多々あるが，より一層の普及が望まれ る.なお今後もっと利用されてよい水や太陽熱を利用し た防災方法を，規模の大小によらず既に行なっている市 町村名を表 4 に示した. 防風対策には柵, 樹木が主に用 いられており，網の使用もみられる．雪崩対策には, 柵, 樹木, 網の他に, シエルターやトンネルなどが利用 されている. 路面滑り防止の手段としては砂が主なもの であるが，薬剤や電力の利用もみられる，な抢これら防 災対策の施行場所を四12に示した (全道平均). グラフの 縦軸は対策をとっている市町村の割合 $\left(N / N_{0}, N_{0}=170\right)$ である. 除排雪, 防風, 雪崩, 路面滑り防止は幹線道路 (a)，生活道路(b)，歩道(c)などの道路を守る方法としてと られており, 田畑(g)においては、融雪 (促進)や防風对策 が主なものである. 先に述べたように, 道内の雪水寒冷 災害といっても，それは交通障害を引き扣こす雪害が主 なものであった。このため防災対策は，雪害から道路を 守る事に主眼が置かれているようだ. な扰各支庁に打い て災害対策の施行率が低いからと言って必ずしも防災体 制の遅れを示すものではなく，むしろその支庁に㧊ける 災害発生頻度が低い事を示していると考えられる。

(3) 利雪・利寒の現状について

これまで述へてきたように雪や寒さは，社会生活に混 乱をもたらす厄介なものである. しかし，近年この雪や 寒さを積極的に利用しようとする気運が盛り上がってき 

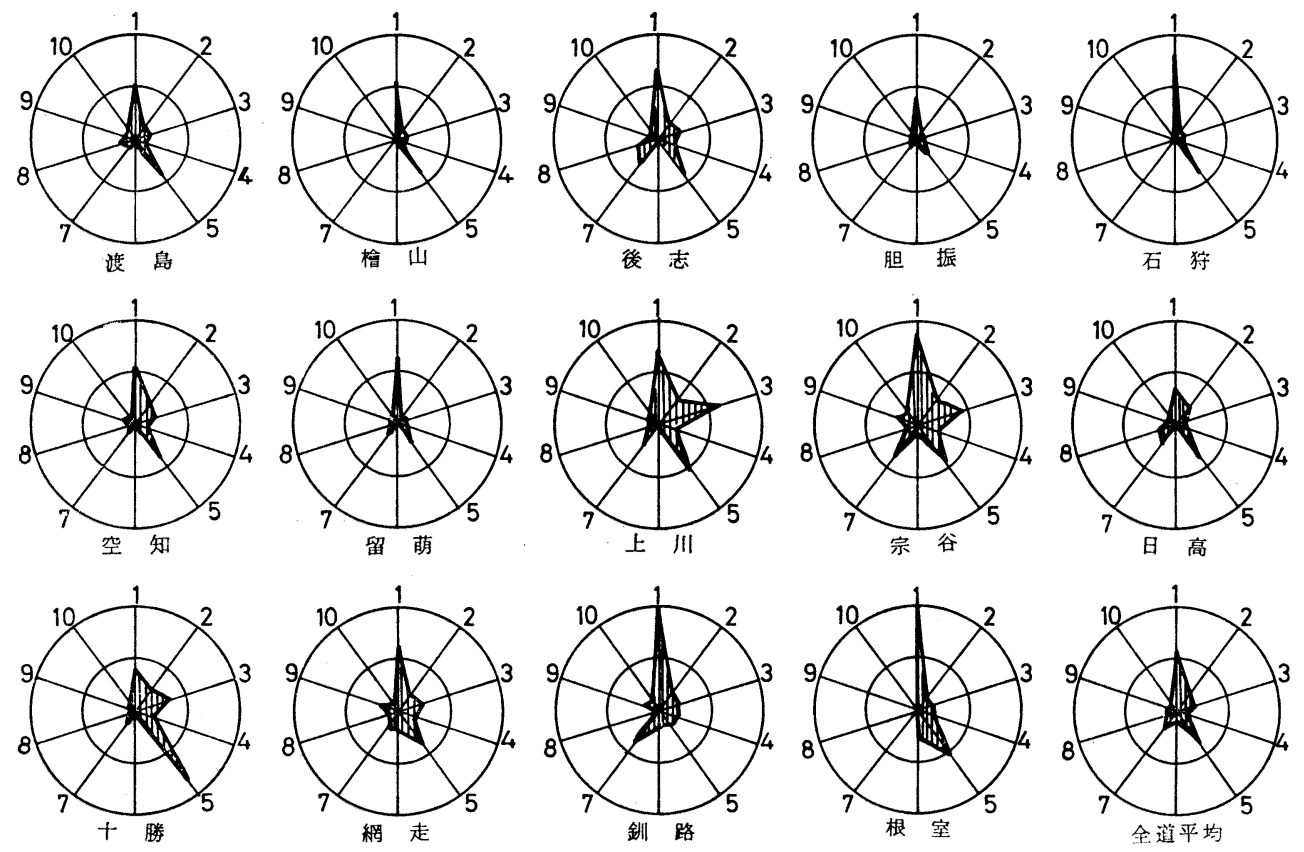

図 8 支庁別全雪水寒冷災害の原因. 外円は $100 \%$, 内円は $50 \%$ の発生頻度

1 : 風と雪（吹雪，吹溜り） $2:$ 季節ハズレの気侯（消雪遅延，遅霜，早い降雪，早霜） $3:$ 低温（異常低温） 4 : 風と寒さ（涷害，寒風害） $5:$ 積雪（豪雪・ト力雪） $6:$ : 流 水（流水・海面凍結） $7:$ 凍上 $8:$ 雪崩 9 : 融雪洪水（出水） 10 : その他（着水雪, 冠雪, 屋根雪滑落, その他)
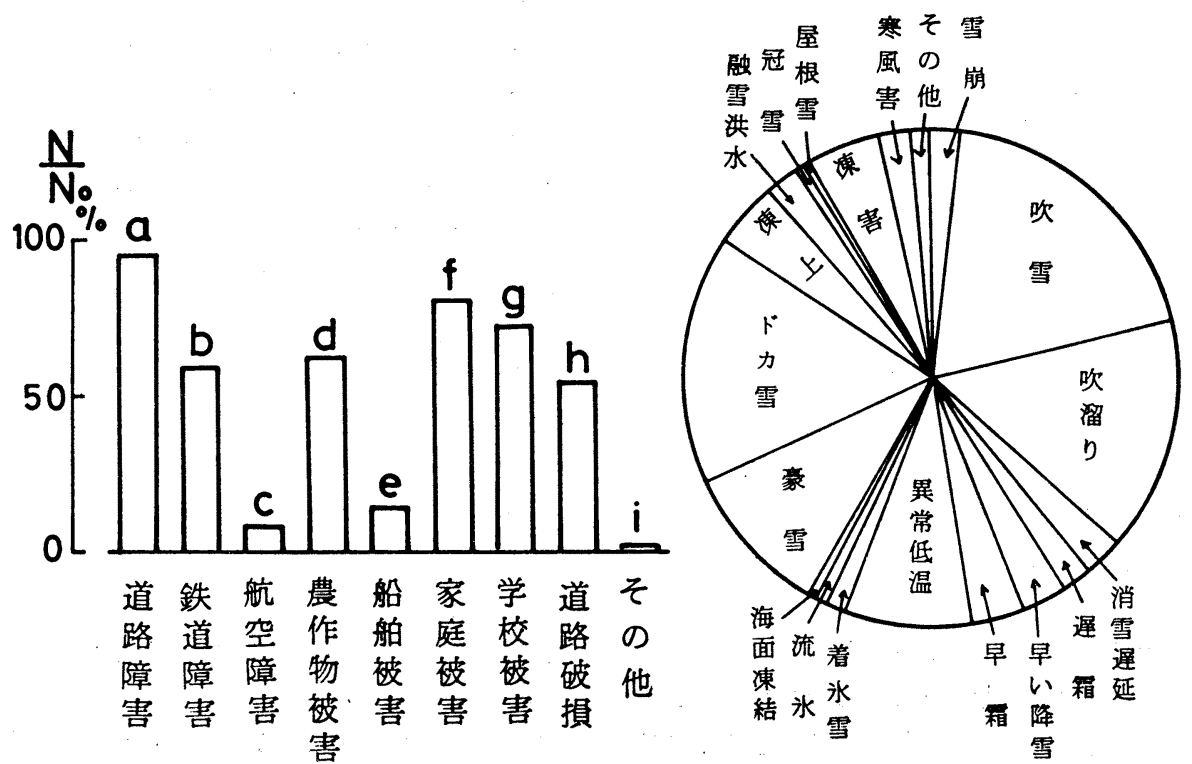

図 9 北海道全域における雪水寒冷災害の種類別発生頻度（棒グラフ）と災害の原因の項目別 割合（円グラフ） 


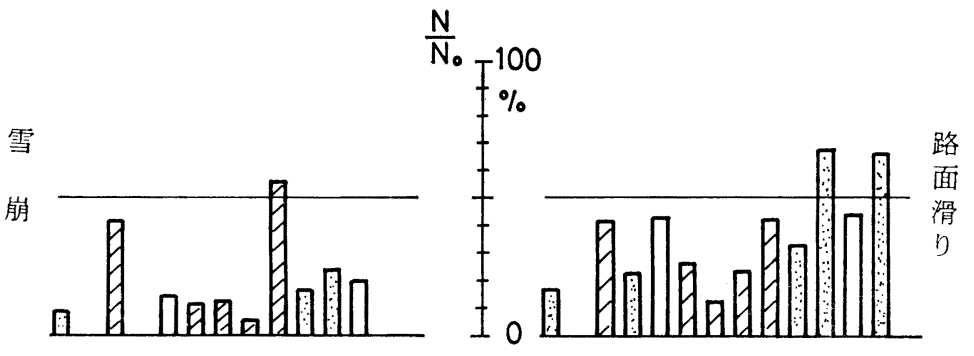

暖

房
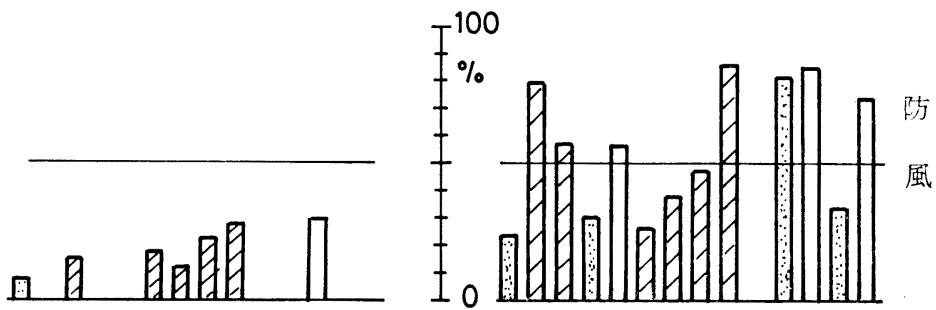

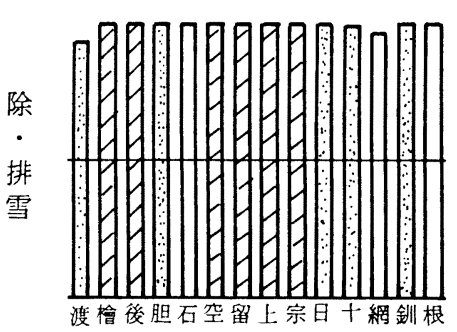

島以志层狩知萌川谷高勝走路室

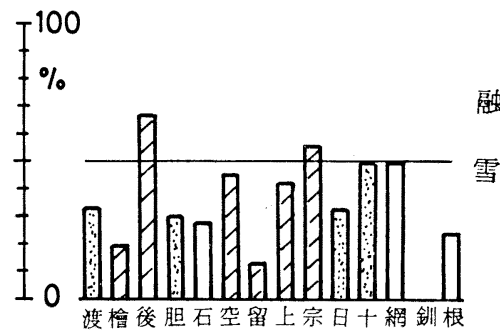

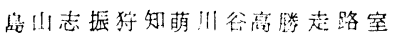

図 10 支庁毎にみた雪氷寒冷災害 の種類別施行率 斜線部, ドット部, 及び白 拔部は図 2 と同じ意味

表 4 具体的災害対策（水や太陽熱利用），及び利雪（寒）を行なっている市町村名

\begin{tabular}{|c|c|c|c|c|c|c|c|c|c|}
\hline & & 渡 島 & 後 志 & 石 狩 & 空 知 & 川 & 宗 谷 & 網 & 留 萌 \\
\hline \multirow{2}{*}{ 災 } & 流雪溝 & & $\begin{array}{lll}\text { 喜 } & \text { 茂 } \\
\text { 別 } & \text { 知 安 }\end{array}$ & & $\begin{array}{l}\text { 滝川, 砂川, } \\
\text { 深川 }\end{array}$ & & & & 増 毛 \\
\hline & 地下水 & 鹿部 & $\begin{array}{l}\text { 俱 知 安, } \\
\text { 古平, 仁木 }\end{array}$ & & $\begin{array}{l}\text { 深 } \\
\text { 秩 父 別 }\end{array}$ & & & 佐 呂 間 & \\
\hline 害 & 温泉水 & $\begin{array}{l}\text { 鹿部, 森, } \\
\text { 長 万 部 }\end{array}$ & 島牧 & & 北 & & & 女 満 別 & \\
\hline 対 & 温排水 & & & & 深川, 北村 & & & 溥別 & \\
\hline 策 & 太陽熱 & & & & & & & $\begin{array}{l}\text { 網走, 端野, } \\
\text { 遠軽 }\end{array}$ & \\
\hline \multirow{2}{*}{$\begin{array}{l}\text { 利 } \\
\text { 雪 } \\
\text { 寒 }\end{array}$} & 冷熱源 & & 泊 村 & 匹島 & 深川, 北村 & $\begin{array}{l}\text { 士別, 当麻, 和寒, } \\
\text { 剣淵, 美深 }\end{array}$ & $\begin{array}{l}\text { 中頓別, } \\
\text { 歌 登 }\end{array}$ & 訓子 府 & \\
\hline & その他 & . & & & 北 & 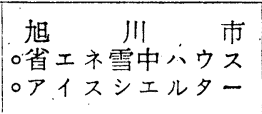 & & 女 満 別 & 苫前町 \\
\hline
\end{tabular}




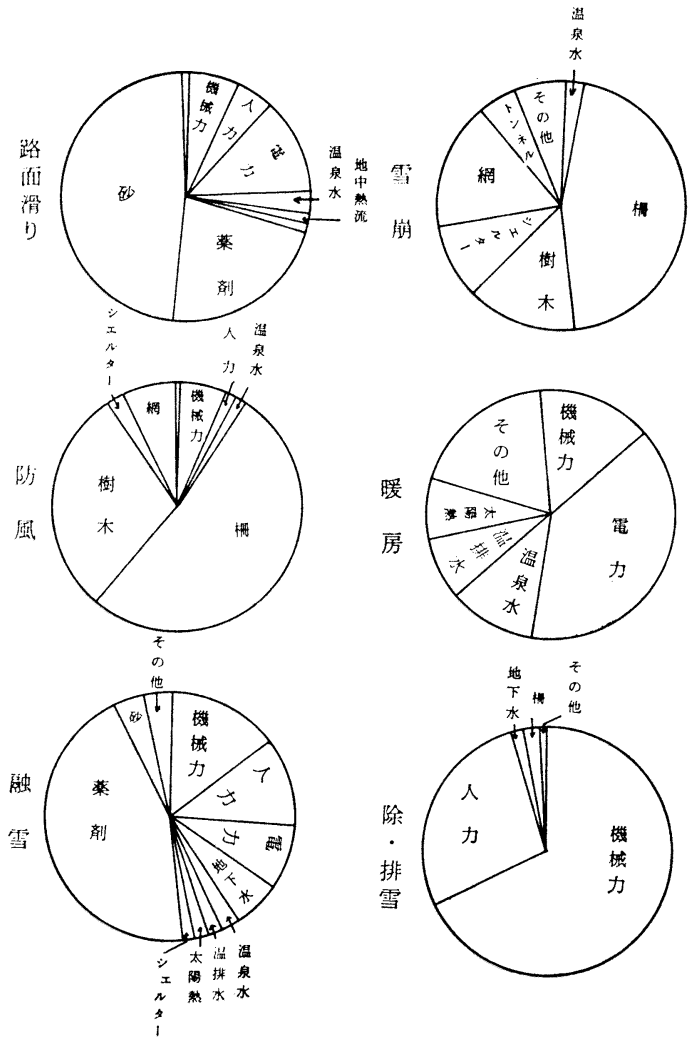

図 11 雪水寒冷災害対策の種類別にみた手段 の割合（全道平均）

た. そこで, 現在道内で実際に行なわれている利雪 (寒) の具体的内容を知るために，(a)観光資源，(b)水資源，(c) 冷熱源，(d)その他の 4 項目を設定して各支庁毎の現状 （図13），及びその内容（図14）を調査した。縦軸はそれ ぞれの項目を行なっている市町村の割合 $\left(N / N_{0}\right)$ であ る.なお図13の上段は利雪(寒)の現状（棒グラフ）と利 雪(寒)の項目別割合（円グラフ）を全道について示した ものである. 渡島，日高両支庁を除いて観光資源として の利用が多く，その内容はスキー（スケート）場として, 又は雪(氷)祭りが主なものである.な技その他(4)の項目 を利雪(寒)として回答した市町村も多く，その内容もス キー（スケート）場が主なものである．これは各自治体 がその地域のスキー（スケート）場を，積極的に観光施 設として考えているか，住民の福祉厚生施設として考え ているかの違いによるものであろう.

道内の河川は山岳地帯の積雪をその源にしているた め, 水資源としての雪の利用は既になされているといえ るが，積極的な水資源の利用は未だ少なく，冷熱源の利 用はさらに少ない, その内で宗谷, 上川, 空知, 石狩,
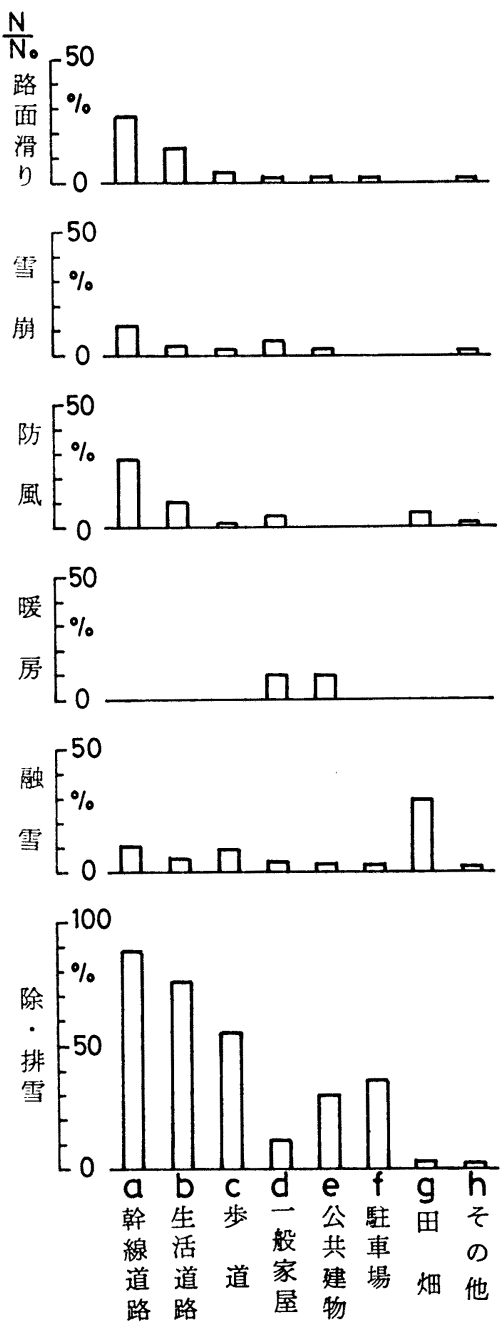

図 12 場所毎にみた災害対策の種類別施行率

後志, 網走の各支庁においては農作物保存等の目的で冷 熱源の利用がみられる.この他に積雪の日射に対する反 射性や高い断熱性を利用した省エネ雪中ハウスや，吹き つけた雪粒の強い結合力（ピータースノー）を利用した アイスシエルター等興味深い報告が旭川市からなされた （表 4). 以上アンケートの調査結果からは，末だ利雪 (寒)が充分に行なわれているとは言いがたい. 今後, 雪 や寒さの特性を把握しながら, 例えば寒地工学的に, さ らには新しいエネルギー源としての雪や寒さを利用する 方法を確立していく必要がある.

今回のアンケート調查は市町村を対象にして行なわれ た. その為, 各自治体がしっかり把握している災害の種 類, 対策, 利雪の各内容に関しては幅広く回答を得た. しかし一般家庭において小規模ながら毎年繰り返し被害 


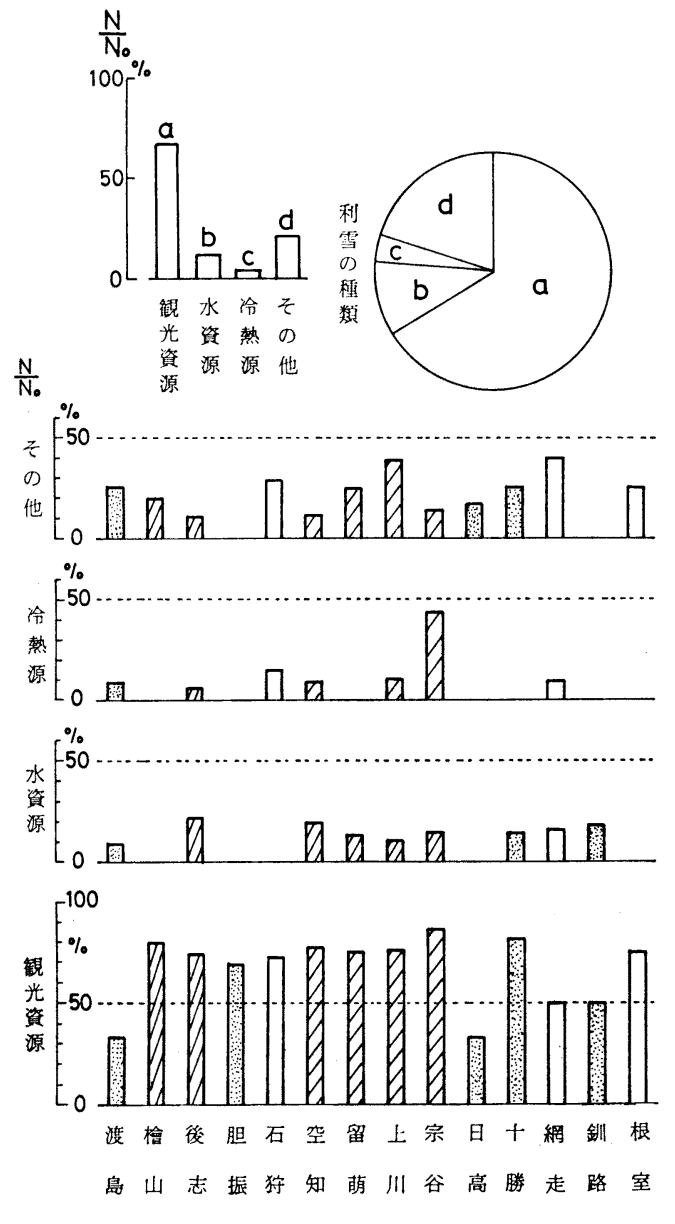

図 13 各支庁毎の利雪, 利寒の現状 斜線部, ドット部, 及び白抜部は 図 2 と同じ意味

を受けている項目（例えば屋根雪，樹木等の雪害・寒害 対策等）に関しては，必ずしも適確な回答を受けたとは 言いがたい，雪水寒冷災害の種類は多く，災害を受ける 分野もそれぞれ異なる事がある．調査する内容により， 調査対象とする機関にも一考を要する.

\section{4. ま と め}

冬の期間が長く，広い面積を有する北海道において雪 亦寒冷災害の原因，その対策及び利雪・利寒の現状につ いて各自治体（市町村）、を対象にアンタート調査を行な った. その結果，1) 災害対策費にはっきりした地域性が 現われ，積雪の多い日本海で多く，寒いが積雪が少ない 太平洋侧では少ない，2）雪氷寒冷災害の中では，道路に 対する障害がもっとも多く報告され, 次いで家庭, 学

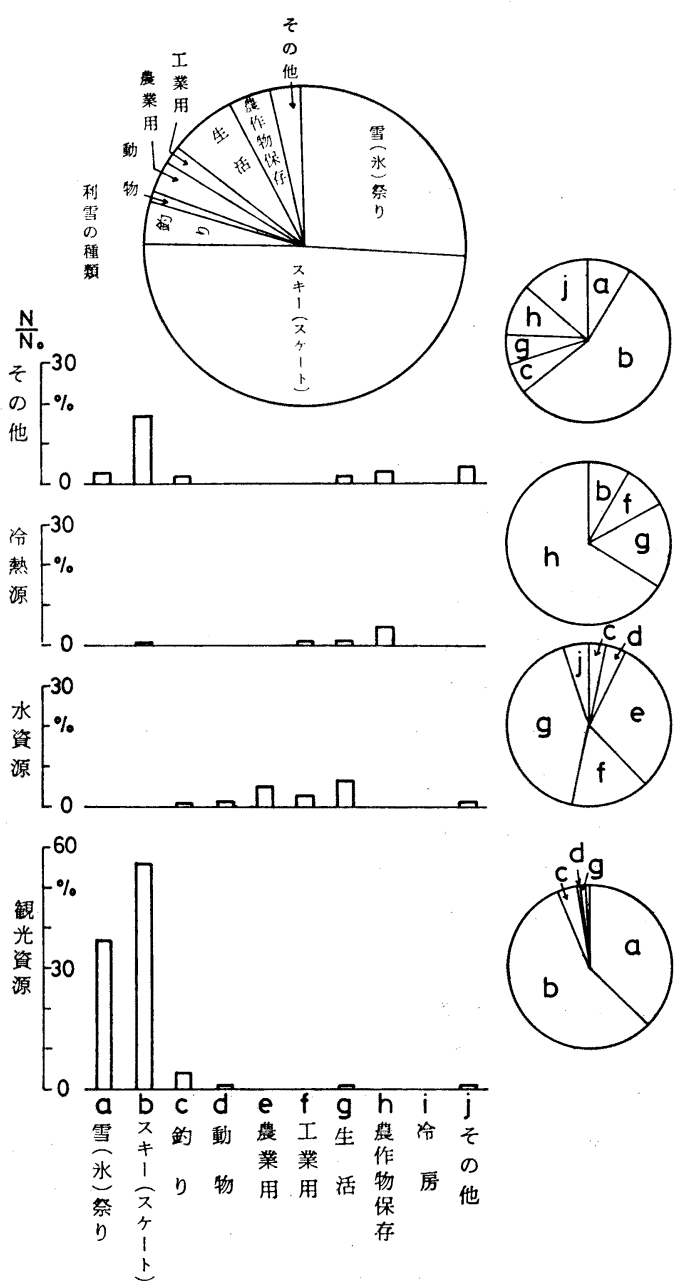

図 14 利雪, 利寒の種類別内容 (全道平均)

校, 農作物, 鉄道の障害が挙げられた. その原因は吹 雪, 吹溜り, 集中豪雪 (ドカ雪), 及び季節ハズレの低 温や冬期の異常低温による．3)雪氷寒冷災害の対策は, 道路を雪から守る除排雪や防風が主なものである．4）雪 や寒さは，スキー（スケート）場，又は雪(水)祭り等の 観光資源としてては既に多くの市町村で利用されている. 一方, 水資源, 又はエネルギ一（冷熱），源としての利用 は未だ低い。しかし規模法小さいが、積極的に雪（寒） を利用する方法も模索されている.

今回のアンケート調查は道内 170 の自治体の協力を得 てなされた. 以下に市町村名を記して深く感謝いたしま す.

渡島松前町, 福島町, 知内町, 大野町, 戸井町, 尻岸 
内町, 溵法華村, 南茅部町, 鹿部町, 砂原町, 森 町, 長万部町 (回収率 : $12 / 17=70.6 \%$ )

桧山 上八国町，厚沢部町，奥尻町，瀬棚町，今金町 $(5 / 10=50.0 \%)$

後志 小樽市, 島牧村, 寿都町, 黒松内町, 蘭越町, 二 セコ町，真狩村，留寿都村，喜茂別町，俱知安 町, 共和町, 岩内町, 泊村, 神恵内村, 積丹町, 古平町, 仁木町, 余市町, 赤井川村 $(19 / 20=$ 95. 0\%)

胆振 室蘭市, 登別市, 伊達市, 豊浦町, 洞爺村, 大滝 村, 壮瞥町, 白老町, 早来町, 追分町, 厚真町, 武川町，穂別町 $(13 / 15=86.7 \%)$

石狩 札幌市, 千歳市, 恵庭市, 広島町, 石狩町, 新篠 津村, 浜益村 $(7 / 9=77.8 \%)$

空知 夕張市, 岩見沢市, 美唄市, 芦別市, 江別市, 赤 平市, 三笠市, 滝川市, 砂川市, 深川市, 北村, 栗沢町, 南幌町, 奈井江町, 上砂川町, 由仁町, 長沼町, 栗山町, 浦臼町, 新十津川町, 妹背牛 町, 秩父別町, 雨竜町, 北竜町, 沼田町, 幌加内 町 $(26 / 28=92.9 \%)$

留萌 留萌市, 增毛町, 小平町, 苫前町, 羽幌町, 初山 別村, 遠別町, 天塩町 $(8 / 9=88.9 \%)$

宗谷 稚内市, 中頓別町, 枝幸町, 歌登町, 豊富町, 礼 文町，利尻町 $(7 / 10=70.0 \%)$

上川 旭川市，士别市，名寄市，富良野市，鷹栖町，当 麻町, 比布町, 愛別町, 上川町, 東川町, 中富良 野町, 南富良野町, 占冠村, 和寒町, 剣洲町, 朝 日町, 風連町, 下川町, 美深町, 音威子拊村, 中 川町 $(21 / 24=87.5 \%)$

日高 日高町, 平取町, 門別町, 新冠町, 静内町, 様似 町 $(6 / 9=66.7 \%)$

十勝 帯広市, 音更町, 上土幌町, 鹿追町, 新得町, 清 水町, 芽室町, 中札内村, 更別村, 広尾町, 幕別 町, 池田町, 豊頃町, 足寄町, 陸別町, 浦幌町 $(16 / 20=80.0 \%)$

網走 網走市, 東藻琴村, 女満別町, 美幌町, 斜里町, 小清水町, 端野町, 訓子府町, 直戸町, 留辺藥 町, 佐呂間町, 常呂町, 生田原町, 遠軽町, 丸瀬 布町, 白滝村, 上湧別町, 湧別町, 興部町, 雄武 町 $(20 / 26=76.9 \%)$

釧路 釧路市, 釧路町, 厚岸町, 鶴居村, 白糠町, 音別
町 $(6 / 10=60.0 \%)$

根室 根室市, 別海町, 中標津町, 標津町 $(4 / 5=80.0 \%)$

\section{文 献}

秋田谷英次, 和泉 薫, 1981：新閒からみた雪害. 自然 災害資料解析, 8, 75-83.

青森県, 1979: 豪雪地带におけるまちづくりのための総 合調査. 地域開発計画基礎調查, No. 54-6-1, 244 pp.

福田正己, 武田一夫, 1975: 北海道における昭和 49 ～50 年冬の積算寒度值の分布. 低温科学, A, 33. 8591.

桶口敬二監修，1983: HAZAMA-No. 2, 雪氷圏へのア プローチ. 間組広報部， $48 \mathrm{pp}$.

北海道開発局調查課，1969：昭和44年 2 月 5 日， 2 月 7 日暴風雪記録. 北海道開発計画調査冬期経済開発調 査資料, $82 \mathrm{pp}$.

北海道開発局道路計画課監修, 1982: 北海道の道路ポケ ットブック. 北海道開発協会, $113 \mathrm{pp}$.

木下誠一編, 1982: 凍土の物理学. 森北出版, $227 \mathrm{pp}$. 北日本新聞社, 1984：とやま雪語り. 北日本新聞社出版 部, $248 \mathrm{pp}$.

国立防災科学技術センター編集，1982：昭和56年豪雪に よる北陸地方の災害現地調査報告. 主要災害調査, 第17号, $392 \mathrm{pp}$.

中峠哲郎，水越允治，1978: 雪害指数ならびに人口にも とづく雪害対策経費の表現. 雪水，40，1，42-46. 中峠哲郎，1981：昭和 $55 ， 56$ 年豪雪によるなだれ，地す ベり災害及び交通障害の調査研究 (代表石原安雄). 自然災害特別研究突発災害研究成果, No. B-55-4, $177 \mathrm{pp}$.

沼野夏生，1982：豪雪地帯市町村における雪害および雪 対策の実態調查資料 (I), 防災科学技術研究資料, 72 号, 1-247.

札幌管区気象台，1981：北海道の霜害，ひょう害. 解説 資料，第 8 号， $165 \mathrm{pp}$.

札幌管区気象台，1983：北海道の気候. 日本気象協会北 海道支部, $319 \mathrm{pp}$,

仙台管区気象台，1974：異常気象調査報告——昭和49年 1 月〜 2 月の東北地方の大雪について—昭和 49 年 異常現象調查報告, $1,78 \mathrm{pp}$. 
Disasters due to snow, ice and/or low temperature in Hokkaido

\author{
Nobuyoshi IshikawA*, Shun'ichi Kobayashi*,**, Kaoru Horiguchi* \\ and Seiiti KInOsITA* \\ * Institute of Low Temperature Science, Hokkaido University, \\ Sapporo 060 \\ ** Research Institute for Hazards in Snowy Area, Niigata University, \\ Niigata 950-21
}

\begin{abstract}
A survey on disasters was conducted for 212 municipalities in Hokkaido in order to search for effective countermeasures against disasters and ways of utilizing the phenomena of winter weather (snow or cold temperature). The rate of the reply was about $80.2 \%$. The following results were obtained.

1. Districts along the Sea of Japan showed higher values of disaster expenditure per person than those on the Pacific seaboard of Hokkaido.

2. Several kinds of disasters were reported, for instance, damage to transportation facilities $\left(N / N_{0}: 94.7 \%\right)$, households $(80.2 \%)$, school life $(71.2 \%)$ and crops $(61.2 \%)$, where $\mathrm{N}_{0}$ is the total number of towns that replied and $\mathrm{N}$ is the number which answered individual questions. The causes of these disasters were mainly blowing snow, snow drift, heavy snowfall and unseasonable low temperature.

3. One of the main countermeasures is snow removal by mechanical power $(99.4 \%)$. Others include protection against wind $(51.2 \%)$, promotion against snowmelt $(41.8 \%)$ and prevention from road slipping $(34.1 \%)$. These are used for preventing traffic networks from snow disaster. The utilization of snow drainage channels was reported as a new method of snow removal, but it is not widely used.

4. Snow and low temperature have already been used as a tourist resource $(60.0 \%)$ such as for ski (skate) facilities and snow (ice) festivals. It is also important to exploit snow and low temperature as a source of water and energy.
\end{abstract}

(1985年 7 月 16 日受付， 8 月 9 日改稿受理） 